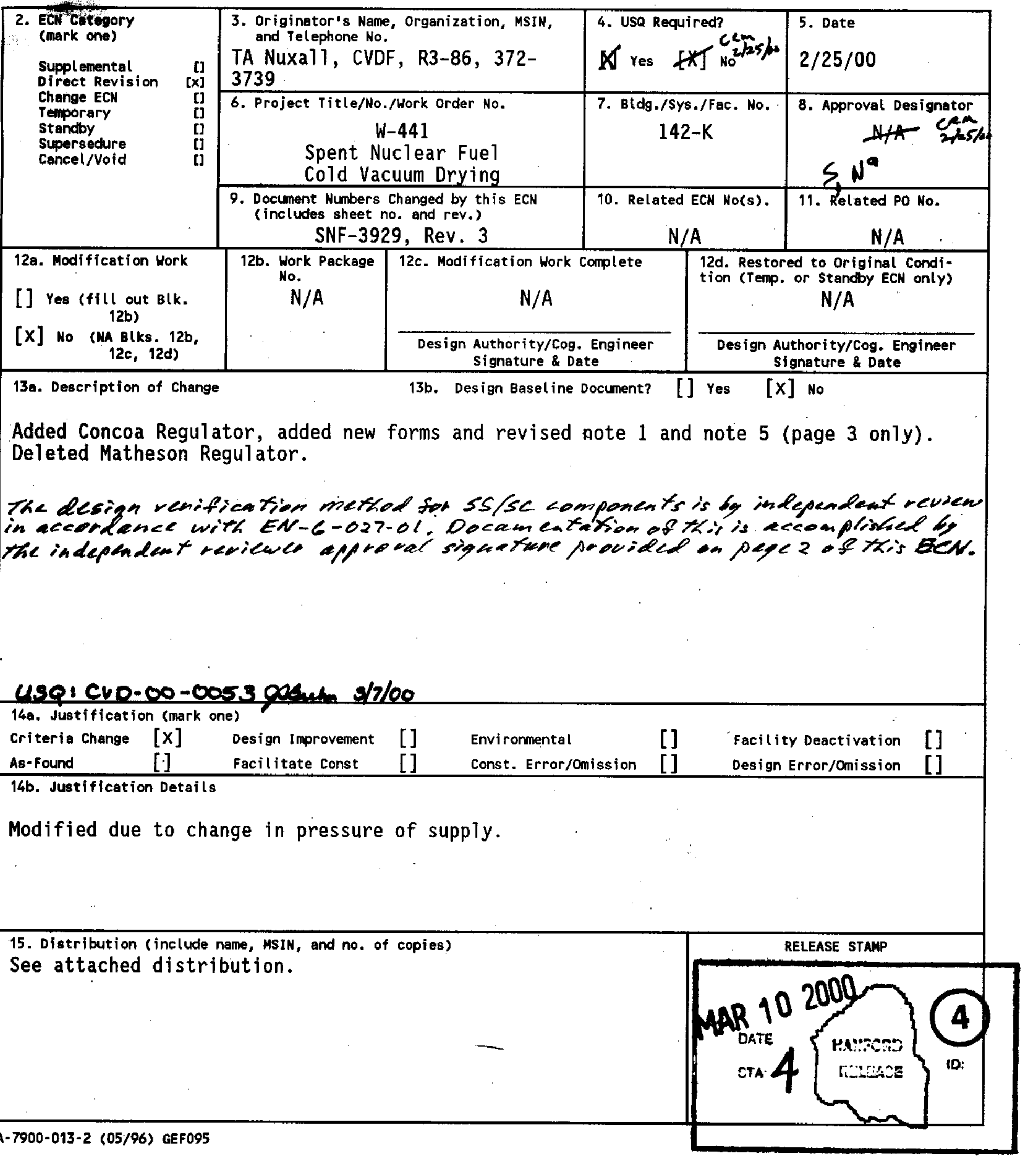




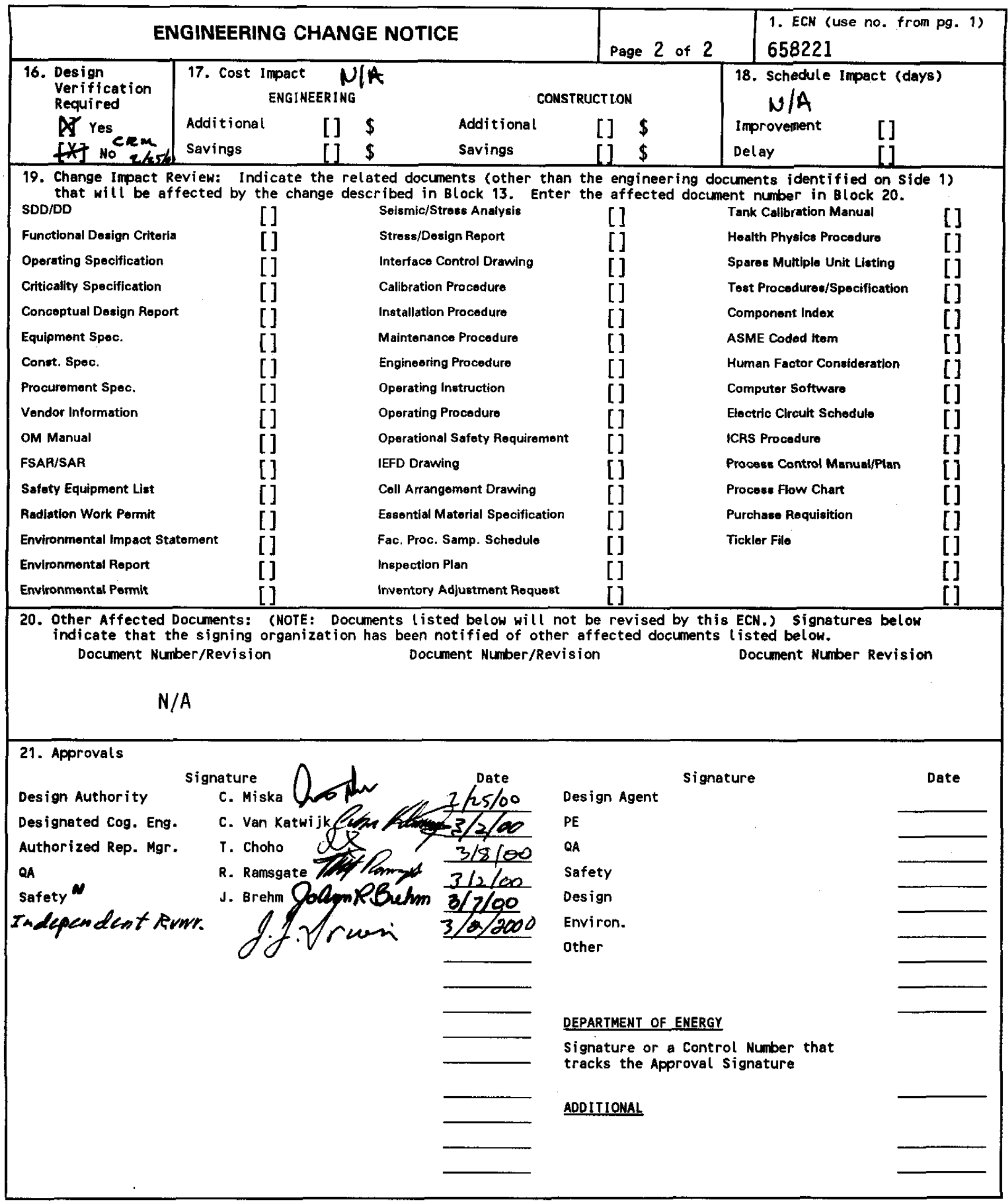




\section{RECORD OF REVISION}

(2) Titte

SNF-3929, CONCOA SCHE PRESSURE REGULATOR (SCHe TANK OUTLET)
(1) Document Number

Change Control Record

(3) Revision

(4) Description of Change - Replace, Add, and Delete Pages

(7)

1 ECN 653776 REVISION TO MEET SEL REV. 6

2

3

$R^{4}$
ECN 647508, REVISION TO MEET SEL REV. 6a

ECN 654031, PART MODEL NUMBER CHANGE

ECN 658221, DELETED MATHISON REGULATOR, ADDED CONCOA REGULATOR, ADDED NEW FORMS
Authorized for Release

\begin{tabular}{l|l} 
(5) Cog. Engr. & (6) Cog. Mgr. Date \\
\hline
\end{tabular}

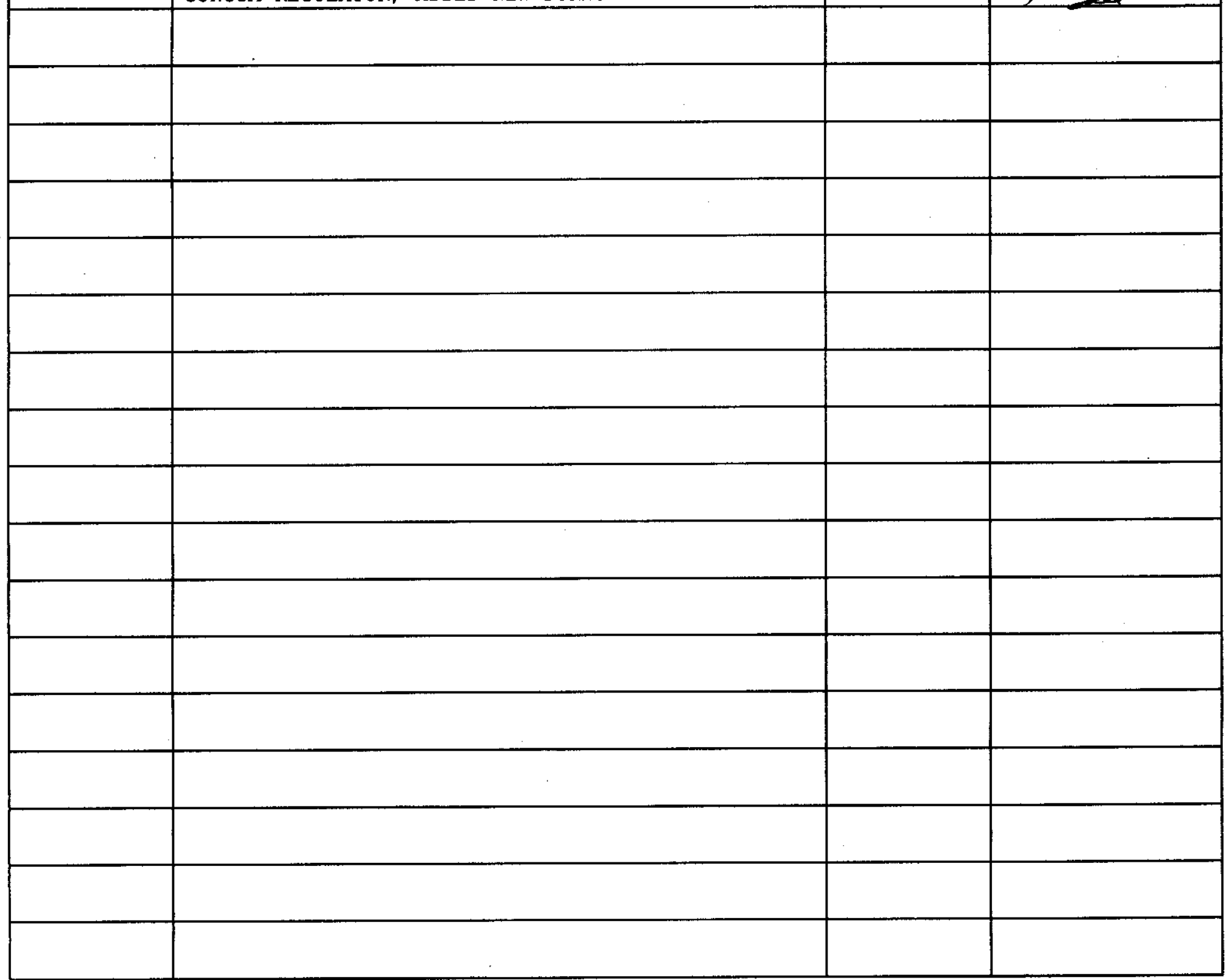




\section{INFORMATION CLEARANCE FORM}

\begin{tabular}{ll}
\hline \multicolumn{2}{|c|}{ A. Information Category } \\
$\square$ Abstract & $\square$ Journal Article \\
$\square$ Summary & $\square$ Internet \\
$\square$ Visual Aid & $\square$ Software \\
$\square$ Full Paper & $\square$ Report \\
$\square$ Other
\end{tabular}

\begin{tabular}{l} 
B. Document Number SNF-3929, Rev. 4 \\
\hline C. Title \\
Concoa SCHe Pressure Regulators (SCHe Tank Outlet) \\
\hline D. Internet Address
\end{tabular}

E. Required Information

1. Is document potentialiy Classified? ONo OYes (MANDATORY)

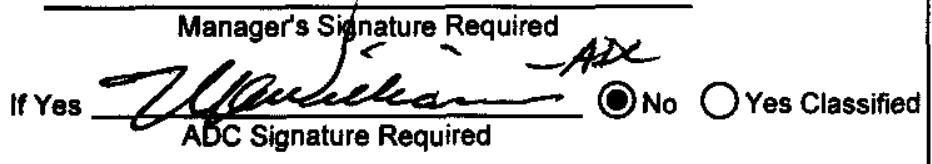

2. Internal Review Required?
If Yes, Document Signatures Below ONo OYes

Counsel

Program

3. References in the Information are Applied Technology ONo OYes

Export Controlled Information

Ono Ores

4. Does Information Contain the Following: (MANDATORY

a. New or Novel (Patentable) Subject Matter? ONo OYes

If "Yes", Disclosure No.:

b. Information Received in Confidence, Such as Proprietary and/or Inventions?

ONo OYes If "Yes", Affix Appropriate Legends/Notices.
c. Copyrights? ONo OYes
If "Yes", Attach Permission.
d. Trademarks?
Ono Ores
If "Yes", Identify in Document.

5. Is Information requiring submission to OSTI? $O$ No $O$ Yes If Yes UC- ___ and $B E R$ -

6. Release Level? $\bigcirc$ Public $\bigcirc$ Limited

7. Charge Code 105559

F. Complete for a Journal Article

1. Title of Journal

G. Complete for a Presentation

1. Titie for Conference or Meeting

2. Group Sponsoring

3. Date of Conference

5. Will Information be Published in Proceedings? $O$ No $O$ Yes

4. City/State

H. Author/Requestor

Treah A. Nuxall

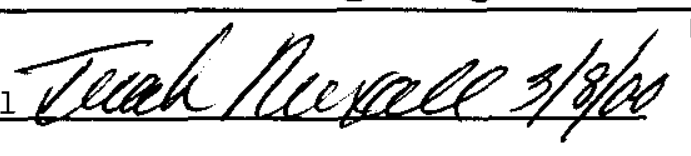

6. Will Material be Handed Out?

Responsible Manager

(Print and Sign)

I. Reviewers

Yes Print

Tarik Choho (Print and Sign)

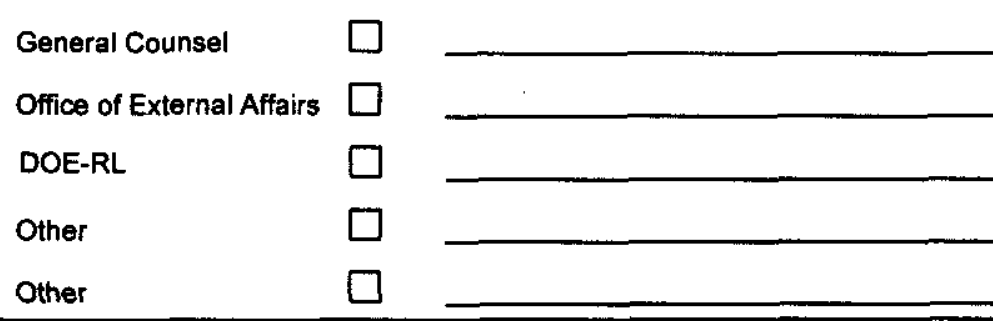

Signature

Public Y/N (If N, complete J)

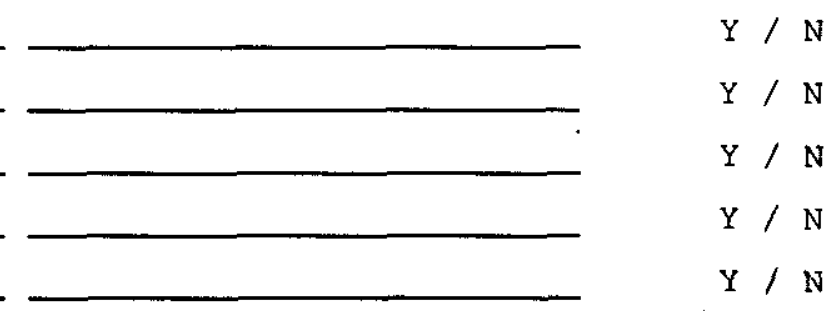

J. If Information Includes Sensitive Information and is not to be released to the Public indicate category below.

$\square$ Applied Technology $\square$ Protected CRADA

$\square$ Personal/Private $\square$ Export Controlled

$\square$ Proprietary $\square$ Procurement-Sensitive

$\square$ Business-Sensitive $\square$ Patentable

$\square$ Predecisional $\square$ Other (Specify)

$\square$ UCN!

K. If Additional Comments, Please Attach Separate Sheet 


\section{RELEASE AUTHORIZATION}

Document Number: SNF-3929, REV 4

Document Title:

Concoa SCHe Pressure Regulators (SCHe Tank Outlets)

This document, reviewed in accordance with DOE Order 241.1, "Scientific and Technical Information Management," and 241.1-1, "Guide to the Management of Scientific and Technical Information," does not contain classified or sensitive unclassified information and is:

\section{APPROVED FOR PUBLIC RELEASE}

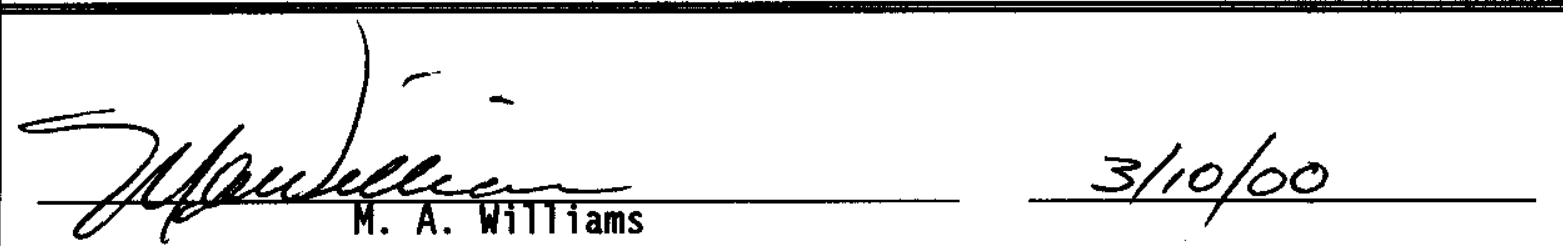

Lockheed Martin Services, Inc.

Document Control/Information Clearance

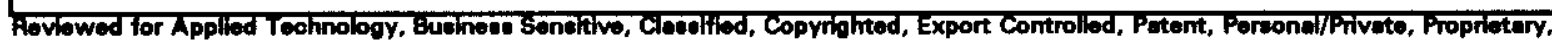
Protected CRADA, Trademark, Unclecelfled Controlled Nuolear Information.

LEGAL DISCLAIMER. This report was prepared as an account of work sponsored by an egency of the United States Government. Neither the United States Government nor any eqency thereof, not any of their employees, nor any of their contractors, euboontrectors or their employees, makee any warranty, exprese or implied, or aseumes any logal Hablity or responsibility for the eccursey.

completenese, or any thind penty's wee or the results of such use of any informetion, apperatus, product, or process dieclosed, or represente thet its use would not infringe privitely owned righte. Roference herein to eny epecific oommerolel produot, procese, or senvee by trede neme, trademark, manuf ecturer, or otherwles, does not necesecrily conetitute or imply its endorsement, recommendation, or fevoring by the United States Government or eny egency thereof or its contrectore or tuboontreotore. The viewe and opinions of authore expresed herein do not neceseerily etete or reflect those of the United Stetes Government or eny eqency thereof. This report has been reproduced from the best avallable copy. Printed in the United states of Amorice. 


\section{Concoa SCHe Pressure Regulators (SCHe Tank Outlet)}

Prepared for the U.S. Department of Energy

Assistant Secretary for Environmental Management

Project Hanford Management Contractor for the

U.S. Department of Energy under Contract DE-AC06-96RL13200

Fluor Hanford

P.O. Box 1000

Richland, Washington 
SNF-3929

Revision 24

\section{Concoa SCHe Pressure Regulators (SCHe Tank Outlet)}

Carl Van Katwijk

Fluor Hanford, Inc.

Date Published

March 2000

Prepared for the U.S. Department of Energy

Assistant Secretary for Environmental Management

\section{Fluor Hanford}

P.O. Box 1000

Richland, Washington

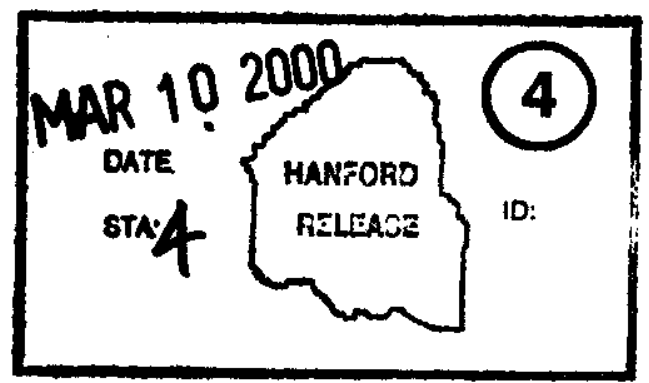


TRADEMARK DISCLAIMER

Reference herein to any specific commercial product, process,

or service by trade name, trademark, manufacturer, or

otherwise, does not necessarily constitute or imply its

endorsement, recommendation, or favoring by the United

States Government or any agency thereof or its contractors or subcontractors.

This report has been reproduced from the best available copy. Available in paper copy and microfiche.

Available electronically at http://www.doe.gov/bridge. Available for a processing fee to the U.S. Department of Energy and its contractors, in paper, from:

U.S. Department of Energy

Office of Scientific and Technical Information

P.O. Box 62

Oak Ridge, TN 37831-0062

phone: 865-576-8401

fax: 865-576-5728

email: reports@adonis.osti.gov(423) 576-8401

Printed in the United States of Americe 


\begin{tabular}{|l|l|}
\hline Commercial Grade Item Upgrade Dedication Form & SNF-3929, Rev. 4 \\
\hline $\begin{array}{l}\text { ECN No. NA CGI No. CGI-SNF-D-13-P5-032 } \\
\text { THte: Concoa SCHe Pressure Regulators (SCHe Tank Outlet) }\end{array}$ & Page 1 of 8 \\
\hline
\end{tabular}

\begin{tabular}{|l|l|l|}
\hline Item No.: N/A & Manufacturer: N/A & Supplier: N/A \\
\hline Mfg. PartModel No.: N/A & Supplier's P/N: N/A \\
\hline
\end{tabular}

Part Description: N/A

End Use Description: N/A

\begin{tabular}{|l|l|l|l|}
\hline $\begin{array}{l}\text { Equipment No.: } \\
\text { SCHe-PCV-5*04, 5*23,5*43, } \\
\mathbf{5}^{* 63}\end{array}$ & $\begin{array}{l}\text { Specification No: } \\
\text { W-441-P5, Rev. } 3\end{array}$ & $\begin{array}{l}\text { Manufacturer: } \\
\text { Concoa }\end{array}$ & $\begin{array}{l}\text { Past P.O. No.: } \\
\text { N/A }\end{array}$ \\
\hline $\begin{array}{l}\text { Procurement and/or } \\
\begin{array}{l}\text { Model No.: } \\
\text { Concoa: } 412-2000-01-0 X A\end{array}\end{array}$ & $\begin{array}{l}\text { Equipment Supplier (if different from manufacturer): } \\
\text { TBD }\end{array}$ & $\begin{array}{l}\text { Equip. Supplier's Part No.: } \\
\text { N/A }\end{array}$ \\
\hline
\end{tabular}

Component Description: Dual Stage Pressure Regulator to Maintain Steady Delivery Pressure Over Wide Range of He Tank Pressure.

1. Is the Item available from a catalogue from a qualified NQA1 supplier or ISO 9000 supplier (coordinate with project CGI interface Engineer or BTR)? [ ] YES (go to \#2 below) [X] NO (go to procedure step 6.3.2, proceed to dedicate ltem) If not available from a qualified NQA1 supplier, is it available from an ISO 9000 supplier? (coordinate w/ project CGI Interface Engineer or BTR):

( ] YES (go to \#2 below, procedure step 6.3.2, dedicate ltem) [X] NO (procedure step 6.3.2, dedicate ltem)

2. List of Candidate qualified suppliers or ISO 9000 suppliers: N/A

3. Recommended Procurement Strategy(coordinate with project CGI interface Engineer or BTR): N/A

CGI Determination Questions:

$\# 1$ : Is the Item subject to design or specification requirements that are unique to nuclear facilities or activities?
l ] YES (the ltem is not commercial grade)
[X] NO (continue)

$\# 2$ : Is the Item used in applications other than nuclear facilities or activities?
[ 1 NO (the item is not commercial grade)
[X] YES (continue)

$\# 3$ : Is the Item ordered from manufacturer/supplier on the basis of specifications set forth in the manufacturer's catalog?

[ ] NO (the item is not commercial grade) [X] YES (continue)

[X] All three criteria have been satisfied. The Item meets the definition of commercial grade. 


\begin{tabular}{|l|l|}
\hline Commercial Grade Item Upgrade Dedication Form & SNF-3929, Rev. 4 \\
\hline $\begin{array}{l}\text { ECN No. NA CGINo. CGI-SNF-D-13-P5-032 } \\
\text { Tite: Concoa SCHe Pressure Regulators (SCHe Tank Outlet) }\end{array}$ & Page 2 of 8 \\
\hline
\end{tabular}

\begin{tabular}{|c|l|}
\hline $\mathrm{X}$ & Item is being purchased from a non-ESL manufacturer supplier as CG to be used in a Safety Class application. \\
\hline & Item is being purchased from a non-ESL manufacturer supplier as CG to be used in a Safety Significant application. \\
\hline & Item was purchased from a non-ESL manufacturer supplier as CG to be used in a Safety Class application. \\
\hline & Item was purchased from a non-ESL manufacturer supplier as CG to be used in a Safety Significant application. \\
\hline & Other (like-for-like', similar, substitution, replacement evaluation) \\
\hline
\end{tabular}

\section{A. Part/Component Safety Function:}

1. Pressure boundary.

2. Prevent Thermal Runaway and $\mathrm{H} 2$ explosion.

3. Maintain critical function before and after seismic event.

B. Part/Component Functional Mode:

Safety Function \#1: [ ] Active [X] Passive

Safety Function \#2: [ ] Active [X] Passive

Safety Function \#3: [] Active $[X]$ Passive

Active - Mechanical or Electrical change of state is required to occur for the component to perform its safely function

Passive - Change of state is not required for the component to pertorm its safety function

C. Host Component Safety Function (if applicable): N/A

1.

D. Failure Mode(s) and the effects on component or system safety function (see Worksheet 1):

1. Valve Body/Process Connection break - loss of boundary, air in-leakage.

2. Diaphragm/Body Failure - loss of regulating function.

Environmental Qualification Required:

Yes [ ]

No [X] Environmental Condition B
If yes: Environmental Qualification Requirements

Limiting Environmental Conditions:

Required Safety Functions:

Qualification Period:

If yes: NPH Design Requirements

Performance Category: PC-3

NPH Design Req'ts.: Selsmic Condition A

Required Safety Functions: Maintain Pressure Boundary, Prevent Thermal Runaway and H2 Explosion, MaIntaln Crtical Function Before and After Selemic Event

\section{W-441-P5, Rev. 3}

$\mathrm{X}$ Safety Class (SC)

If part/component classification is different from host component/system, document basis. N/A

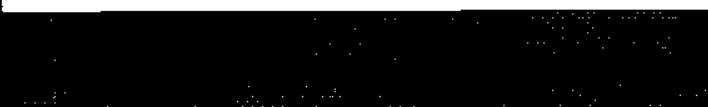

National Codes/Standards: ASME B31.3

Safety Analysis Report (SAR): HNF. 3553, Rev. 0, Annex B

Drawings: H-1-82165, Rev. 2, HNF-SD-SNF-SEL-002, Rev. 7

Vendor Manual/Manufacturer/Supplier Information: Catalog Cut Sheets: Concoa 412 Series Regulator 


\begin{tabular}{|l|l|}
\hline Commercial Grade Item Upgrade Dedication Form & SNF-3929, Rev. 4 \\
\hline $\begin{array}{l}\text { ECN No. NA CGI No. CGI-SNF-D-13-P5-032 } \\
\text { Titte: Concoa SCHe Pressure Regulators (SCHe Tank Outlet) }\end{array}$ & Page 3 of 8 \\
\hline
\end{tabular}

Critical Characteristics

Acceptance Criteria/Tolerances

\begin{tabular}{|c|c|c|}
\hline $\begin{array}{c}\text { Acceptance } \\
\text { Method }\end{array}$ & 10 & Function \\
\hline
\end{tabular}

1. Item Identification Critical Characteristics (necessary for reasonable assurance that the Item delivered is the ltem specified)

\begin{tabular}{|c|c|c|c|}
\hline Nameplate - Manufacturer & Concoa & $1, \mathrm{IN}$ & $\underline{x}$ \\
\hline $\begin{array}{l}\text { Regulator Component Number- } \\
\text { Procurement and/or Model Number }\end{array}$ & $\begin{array}{l}\text { 412-2000-01-0XA, (Per Procurement Package W- } \\
\text { 441-P5, Rev. 3, Design Data Sheet) }\end{array}$ & 1, IN & $x$ \\
\hline $\begin{array}{l}\text { Rellef Valve Manufacturer/Model No. } \\
\text { (furnished with regulator) }\end{array}$ & Concoa / 534-922-50, (dilto above) & 1, IN & $x$ \\
\hline $\begin{array}{l}\text { Pigtail Manufacturer/Model No.I } \\
\text { Connection Slze / Length (furnished } \\
\text { with regulator) }\end{array}$ & $\begin{array}{l}\text { Concoa / 529-0070-680 / 1/4" MNPT / 2', (ditto } \\
\text { above) }\end{array}$ & 1, IN & $x$ \\
\hline $\begin{array}{l}\text { Panel Mount Kit Manufacturer/Model } \\
\text { No. (furnished with regulator) }\end{array}$ & Concoa / 550-0002, (ditto above) & 1, IN & $x$ \\
\hline $\begin{array}{l}\text { Hellum Leak Certification (supplied } \\
\text { with regulator) }\end{array}$ & $\begin{array}{l}\text { Documentation of leakage }<1 \times 10^{-8} \mathrm{scc} / \mathrm{sec} \text {, } \\
\text { (ditto above) }\end{array}$ & 1, IN & $x$ \\
\hline
\end{tabular}

2. Physical Critical Characteristics (for reasonable assurance that the ltem delivered is the Item specified)

\begin{tabular}{|l|l|c|c|c|}
\hline Regulator Body Material & Brass (Note 4) & 1, IN, 1, T & X & X \\
\hline Regulator Outlet Connection & 1/4" NPT Male & 1, N & X & \\
\hline
\end{tabular}

3. Performance Critical Characteristics (for reasonable assurance that the ltem will perform its intended safety function(s))

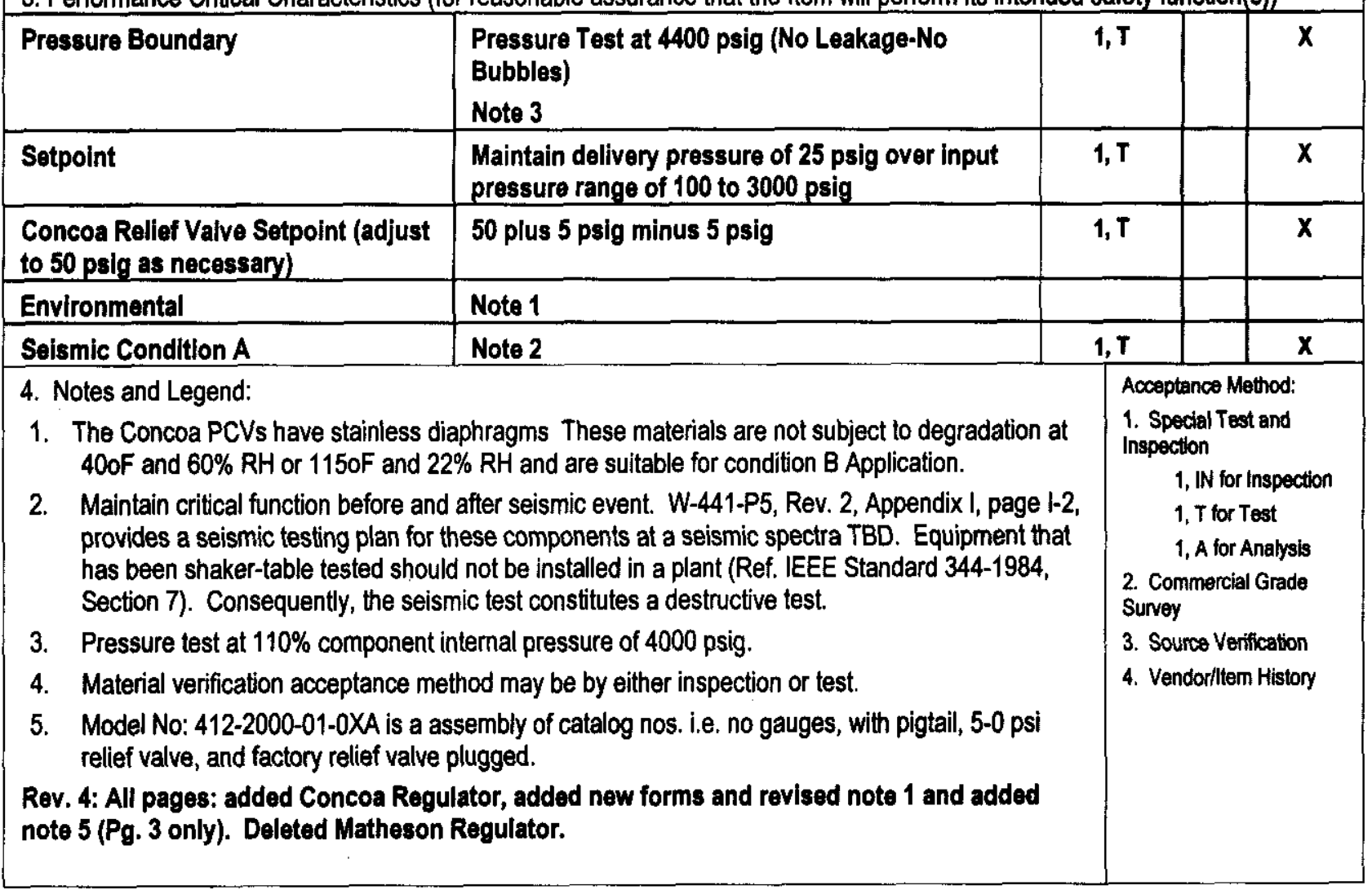




\begin{tabular}{|l|l|}
\hline Commercial Grade Item Upgrade Dedication Form & SNF-3929, Rev. 4 \\
\hline $\begin{array}{l}\text { ECN No. NA CGI No. CGI-SNF-D-13-P5-032 } \\
\text { Titte: Concoa SCHe Pressure Regulators (SCHe Tank Outlet) }\end{array}$ & Page 4 of 8 \\
\hline
\end{tabular}

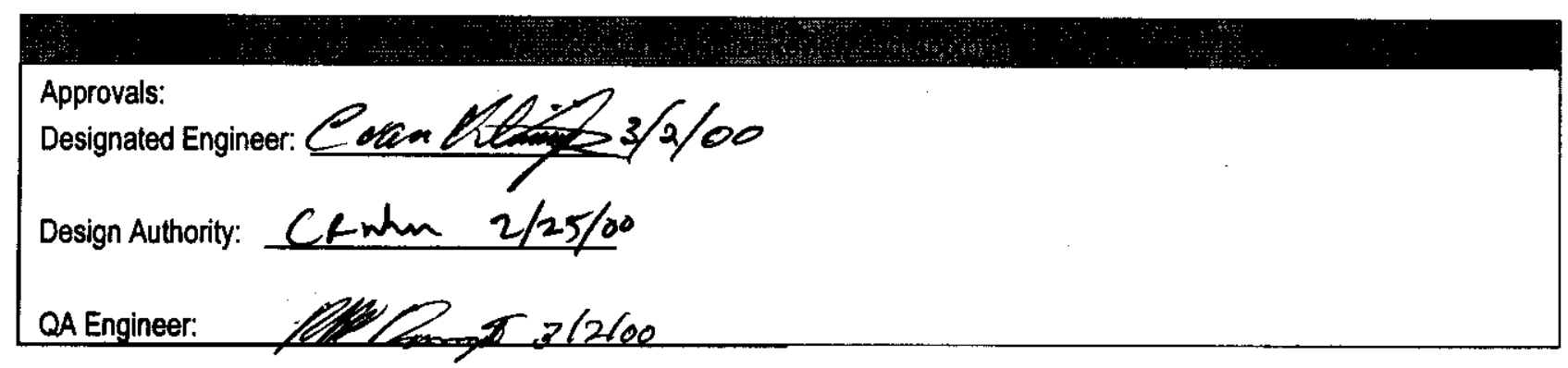

Worksheet 1 - Determination Of Failure Mechanisms

\begin{tabular}{|c|c|c|}
\hline $\begin{array}{l}\text { Typical Failure } \\
\text { Mechanisms }\end{array}$ & Definition & $\begin{array}{l}X=\text { Applicable to Component under Evaluation } \\
X ? \quad \text { Indicate Faliure Mode }\end{array}$ \\
\hline Fracture & $\begin{array}{l}\text { Separation of a solid accompanied by little or no } \\
\text { macroscopic plastic deformation. }\end{array}$ & \\
\hline Corrosion & $\begin{array}{l}\text { The gradual deterioration of a material due to chemical } \\
\text { or electrochemical reactions, such as oxidation, between } \\
\text { the material and its environment. }\end{array}$ & \\
\hline Erosion & $\begin{array}{l}\text { Destruction of materials by the abrasive action of moving } \\
\text { fluids, usually accelerated by the presence of solid } \\
\text { particles carried with the fluid. }\end{array}$ & \\
\hline Open Circuit & $\begin{array}{l}\text { An electrical circuit that is unintentionally broken so that } \\
\text { there is no complete path for current flow. }\end{array}$ & \\
\hline Short Circuit & $\begin{array}{l}\text { An abnomal connection by which an electrical current is } \\
\text { connected to ground, or to some conducting body, } \\
\text { resulting in excessive current flow. }\end{array}$ & \\
\hline Blockage & $\begin{array}{l}\text { Clogging of a filtering medium resulting in the inability to } \\
\text { perform its purification function or blockage of flow. }\end{array}$ & \\
\hline Seizure & $\begin{array}{l}\text { Binding of a normally moving item through excessive } \\
\text { pressure, temperature, friction, jamming. }\end{array}$ & \\
\hline Unacceptable Vibration & $\begin{array}{l}\text { Mechanical osclllations produced are beyond the defined } \\
\text { permissible limits due to unbalancing, poor support, or } \\
\text { rotation at critical speeds. }\end{array}$ & \\
\hline Loss of Properties & $\begin{array}{l}\text { A loss of mechanical and physical properties of a } \\
\text { material due to exposure to high temperatures, radiation } \\
\text { exposure. }\end{array}$ & \\
\hline Excess Strain & $\begin{array}{l}\text { Under the action of excessive external forces the } \\
\text { material of the part has been deformed or distorted. }\end{array}$ & \\
\hline Mechanical Creep & $\begin{array}{l}\text { From prolonged exposure to high temperature and } \\
\text { stress, the object will show a slow change in its physical } \\
\text { (shape and dimension) and mechanical characteristics. }\end{array}$ & \\
\hline Ductile Fracture & $\begin{array}{l}\text { Fracture characterized by tearing of metal accompanied } \\
\text { by appreciable gross plastic deformation. }\end{array}$ & \\
\hline \multicolumn{3}{|c|}{ 1. Regulator Body Break } \\
\hline \multicolumn{3}{|c|}{ 2. Dlaphragm BreakJFailure } \\
\hline
\end{tabular}




\begin{tabular}{|l|l|}
\hline Commercial Grade Item Upgrade Dedication Form & SNF-3929, Rev. 4 \\
\hline ECN No. NA CGI No. CGI-SNF-D-13-P5-032 & Page 5 of 8 \\
Tite: Concoa SCHe Pressure Regulators (SCHe Tank Outlet) & \\
\hline
\end{tabular}

Checklist 1-Acceptance Method 1 - Special Test/Inspection Verification

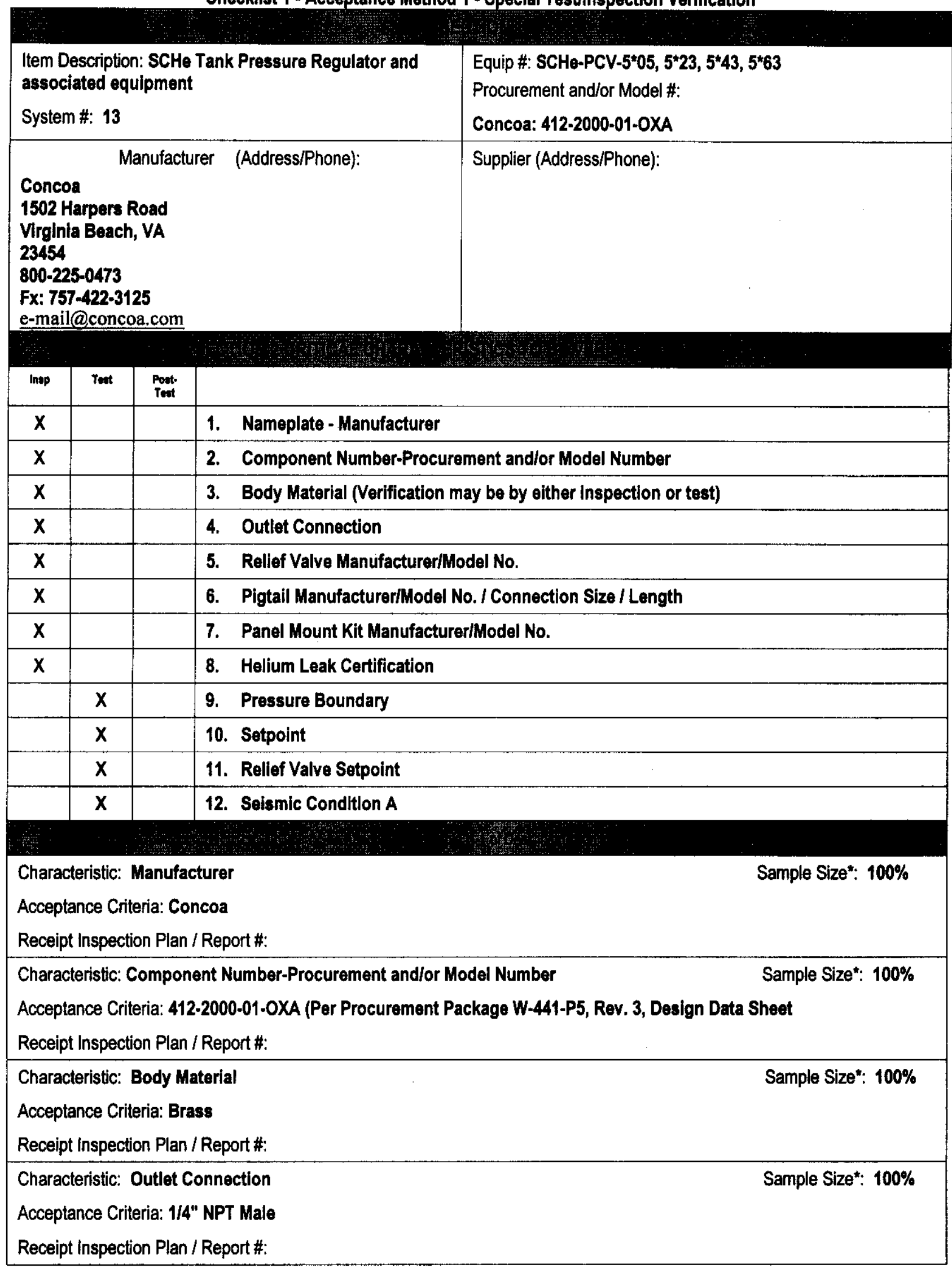




\begin{tabular}{|l|l|}
\hline Commercial Grade Item Upgrade Dedication Form & SNF-3929, Rev. 4 \\
\hline $\begin{array}{l}\text { ECN No. NA CGI No. CGI-SNF-D-13-P5-032 } \\
\text { Titte: Concoa SCHe Pressure Regulators (SCHe Tank Outlet) }\end{array}$ & Page 6 of 8 \\
\hline
\end{tabular}

Characteristic: Relief Valve ManufactureriModel No (supplied with regulator)

Sample Size*: $100 \%$

Acceptance Criteria: Concoa / 534-922-50

Receipt Inspection Plan / Report\#:

Characteristic: Pigtall Manufacturer/Model No. I Connection Size / Length (supplied with regulator) Sample Size*: 100\%

Acceptance Criteria: Concoa / 529-0070-680/1/4" MNPT / 2'

Receipt Inspection Plan / Report\#:

Characteristic: Panel Mount Kit Manufacturer/Model No. (supplied with regulator)

Sample Size*: $100 \%$

Acceptance Criteria: Concoa / 550-0002

Receipt Inspection Plan / Report\#:

Characteristic: Helium Leak Certification (supplied with regulator)

Sample Size": $100 \%$

Acceptance Criteria: $<1 \times 10^{-8} \mathrm{scc} / \mathrm{sec}$

Receipt Inspection Plan / Report\#:

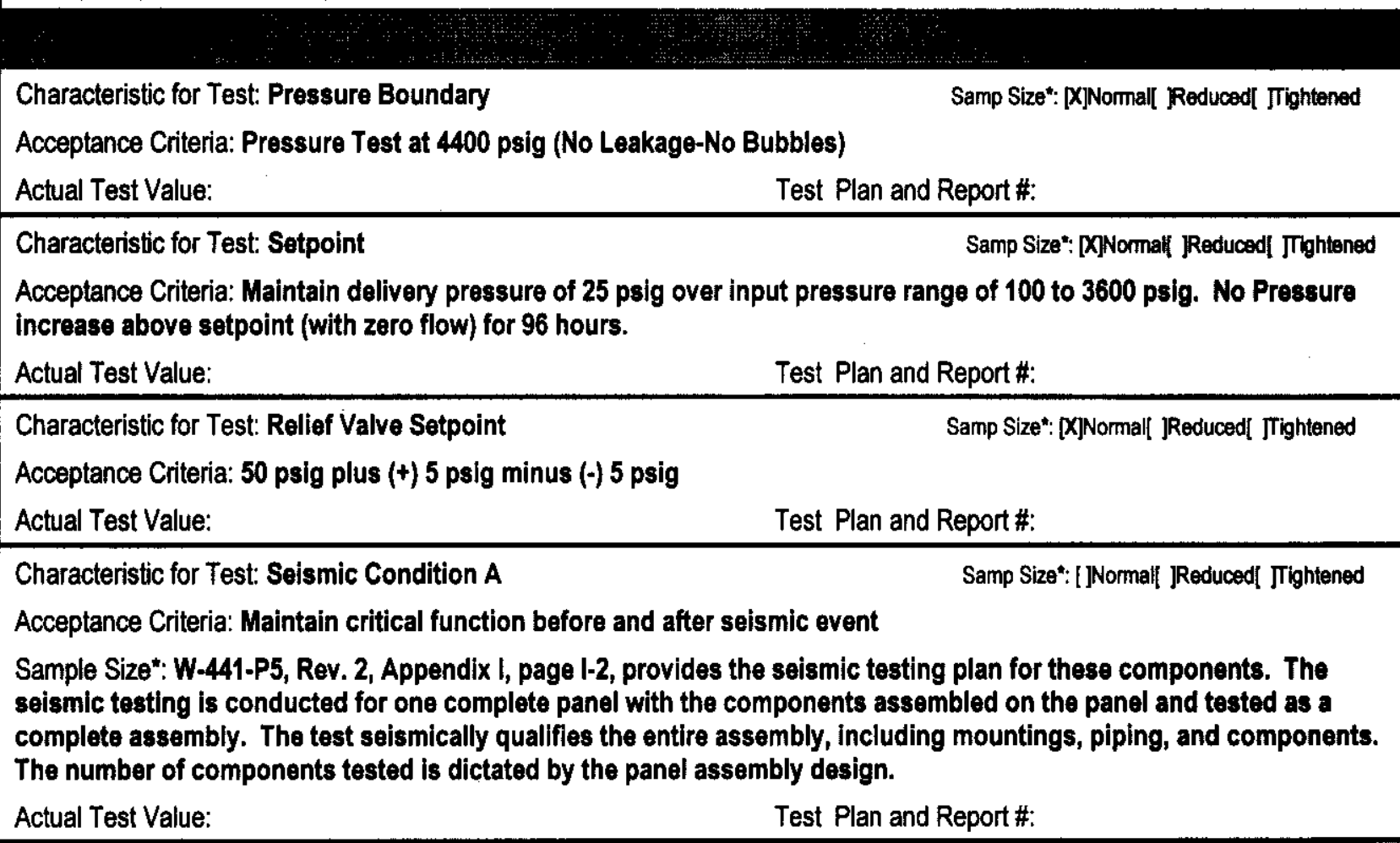

*If Supplier/Manufacturer or Other, Refer to CGI Checklist-2 for Support Information 


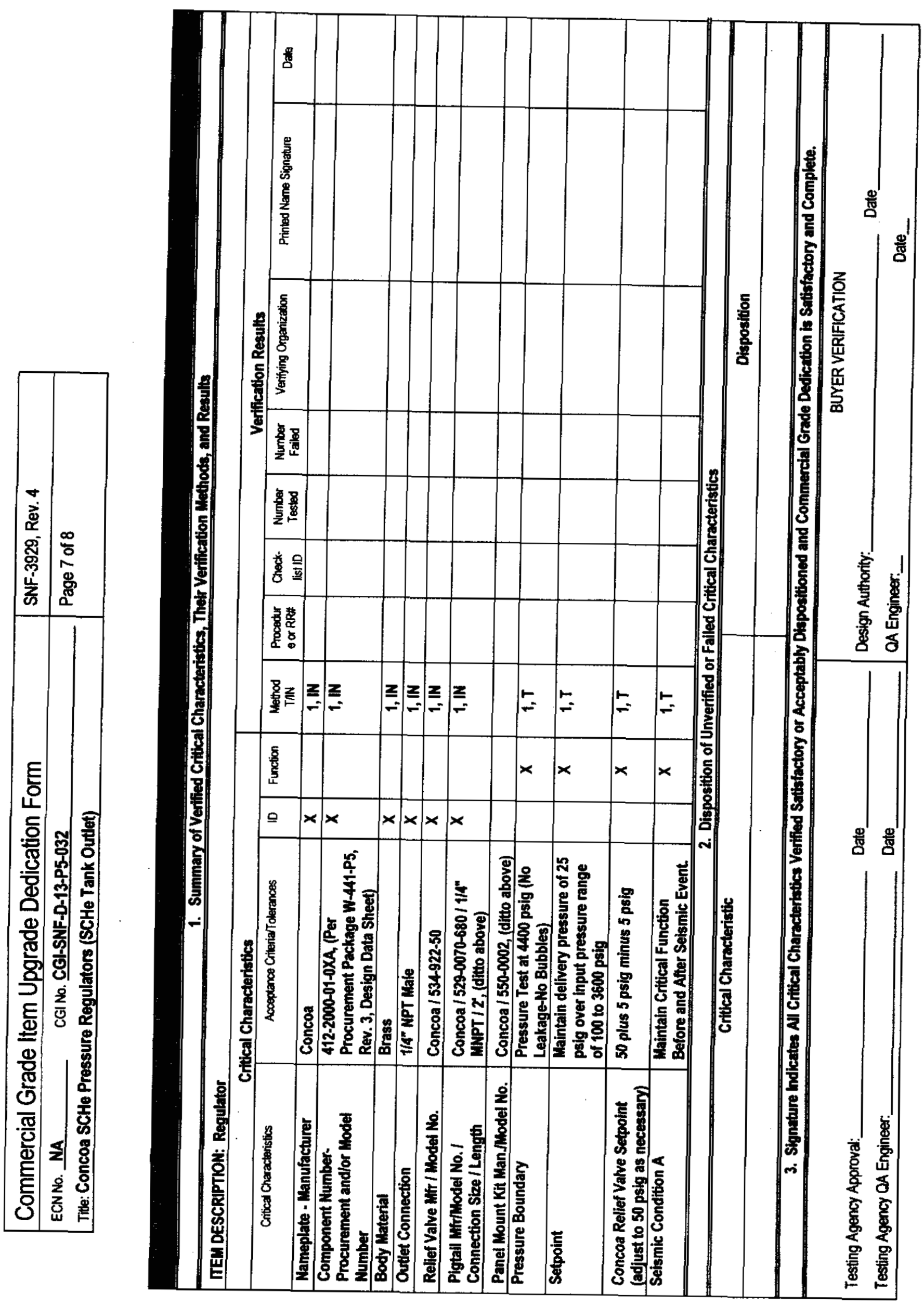




\begin{tabular}{|l|l|}
\hline Commercial Grade Item Upgrade Dedication Form & SNF-3929, Rev. 4 \\
\hline $\begin{array}{l}\text { ECN No. NA CGI No. CGI-SNF-D-13-P5-032 } \\
\text { Titte: Concos SCHe Pressure Regulators (SCHe Tank Outlet) }\end{array}$ & Page 8 of 8 \\
\hline
\end{tabular}

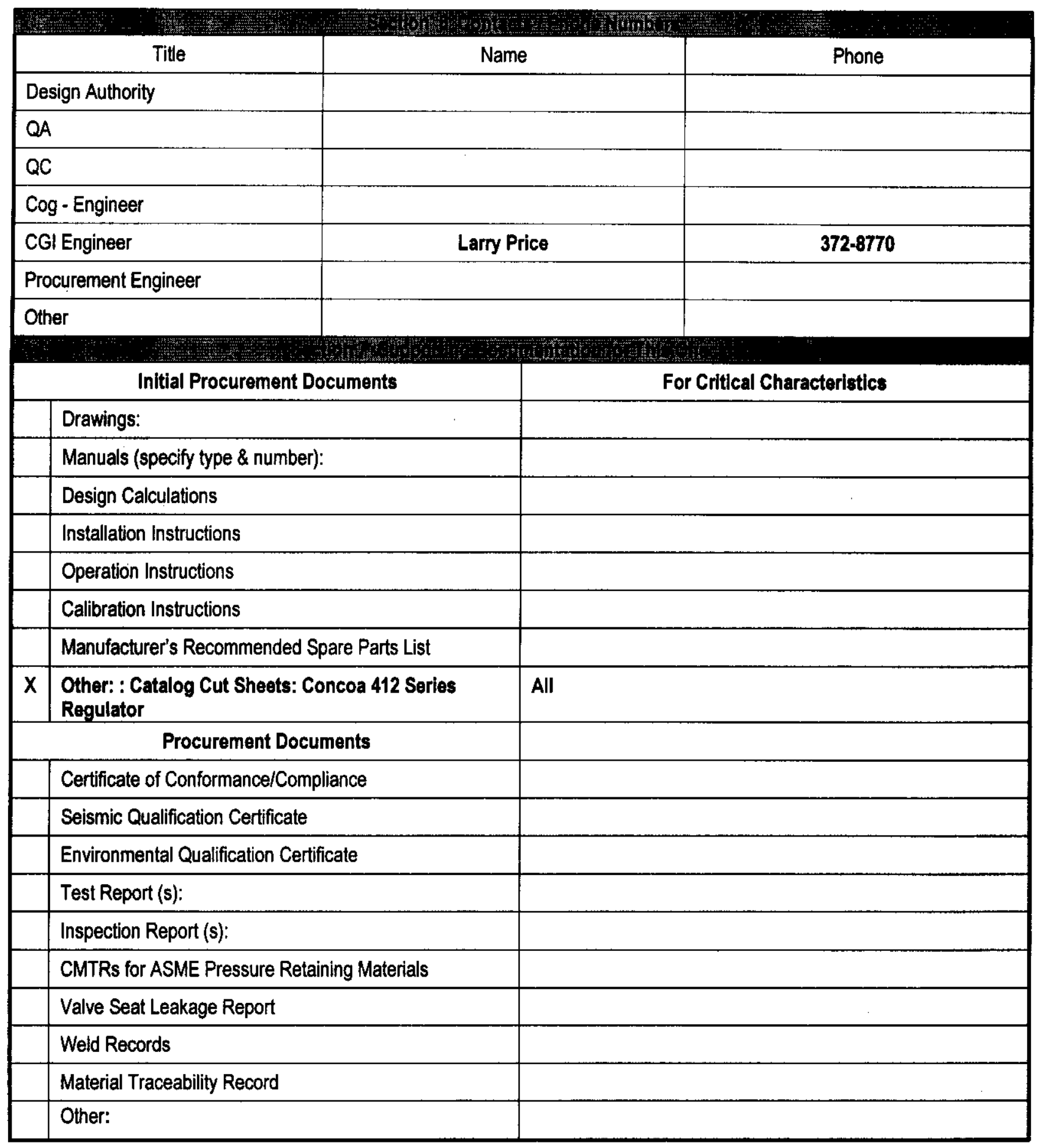




\section{DISTRIBUTION SHEET}

To

Distribution

Project Title/Work Order

W-441，SNF-3929，Rev. 4

\section{From}

T. Nuxal1, SNF-CVD

Name

D. Whitehurst

G. Signh

A. Artzer (CVD Library)

R. Ramsgate

J. Brehm

P. Beaudet

P. Morrell (AVS)

M. Evarts (AI)

L. Price

SNF Startup

SNF Project Files

SNF Satelite Library

C. Van Katwijk

D. Whitworth

T. Nuxall

c. mislca

Page 1 of 1
Date $2 / 25 / 00$

EDT No. N/A

ECN No. 658221

\begin{tabular}{|c|c|c|c|c|} 
MSIN & $\begin{array}{c}\text { Text } \\
\text { With All } \\
\text { Attach. }\end{array}$ & Text Only & $\begin{array}{c}\text { Attach.l } \\
\text { Appendix } \\
\text { Only }\end{array}$ & $\begin{array}{c}\text { EDT/ECN } \\
\text { Only }\end{array}$ \\
\hline
\end{tabular}

